\title{
Morphological Analysis on the Occipital Condyles and Review of the Literature
}

\author{
Análisis Morfológico de los Cóndilos Occipitales y Revisión de la Literatura
}

José Aderval Aragão'; Guilherme Machado de Santana²; Rebeca Zelice da Cruz de Moraes²; Iapunira Catarina Sant'Anna Aragão ${ }^{3}$; Felipe Matheus Sant'Anna Aragão ${ }^{3}$ \& Francisco Prado Reis ${ }^{4}$

\begin{abstract}
ARAGÃO, J. A.; DE SANTANA, G. M.; DA CRUZ DE MORAES, R. Z.; ARAGÃO, I. C. S.; ARAGÃO, F. M. S.; REIS, P. F. Morphological analysis on the occipital condyles and review of the literature. Int. J. Morphol., 35(3):1129-1132, 2017.

SUMMARY: Most anatomical and biomechanical studies on the craniovertebral junction have involved morphological or morphometric analysis on the occipital condyles. Some of these studies have provided important findings based on different surgical procedures. The shape, size and angle of the occipital condyles and the locations of the intracranial and extracranial orifices of the hypoglossal canal are highly important because they may affect the lateral approaches to the craniovertebral junction. To determine the frequency of occurrence of different morphological types of occipital condyle. 214 occipital condyles in 107 dry human skulls were analyzed and the classification of their morphological types was determined through assessing digitized photographic images. Among the 107 skulls analyzed, $59.8 \%$ were male and $40.2 \%$ were female. Their ages ranged from 11 to 91 years, with a mean of 57.56 years. Of the total of 10 morphological types of occipital condyle that were found, more than $50 \%$ were of the " 8 ", "S" and ring types. Condyles of " 8 " and "S" shape were the main types found in male skulls: the " 8 " shape prevailed on the left side and the "S" shape on the right side. However, in female skulls, these two types had equal bilateral distribution.
\end{abstract}

KEY WORDS: Skull; Occipital condyle; Atlanto-occipital joint; Surgical anatomy; Craniofacial abnormalities; Morphology; Occipital bone.

\section{INTRODUCTION}

Assessment and morphological analysis on the bones that make up the neurocranium and viscerocranium of the human skeleton are very important in forensic anthropology and play a significant role in investigations to estimate and determine the sex, age, ethnicity and height of unknown individuals (Kumar \& Nagar, 2014).

The occipital condyles are anatomical structures that are located laterally to the foramen magnum of the occipital bone, at the external base of the skull (Kavitha et al., 2013; Natsis et al., 2013). These structures make a connection with the vertebral column through the atlanto-occipital joint (Kavitha et al., Bayat et al., 2014; Das at al., 2006; Naderi et al., 2005; Ozer et al., 2011; Kizilkanat et al., 2006). The integrity of the occipital condyles is very important for the stability of the craniovertebral junction, such that variations in their shape, size and angle correspond equally to variations in the atlanto-occipital joint (Naderi et al., Ozer et al.).

The occipital condyles have been described as bone structures with an oval outline that are arranged obliquely in such a way that the anterior extremity is more medial than the posterior extremity, thus presenting a convex anteroposterior surface (Kavitha et al.; Ozer et al.). The condylar canal is located posteriorly to the occipital condyles. In some cases, the occipital condyles may project significantly towards the foramen magnum (Muthukumar et al., 2005). The canal of the hypoglossal nerve is located at the anterolateral margin of this foramen (Kizilkanat et al.).

\footnotetext{
${ }^{1}$ Associate Professor, Department of Morphology and the Postgraduate Applied Health Science Programs, Federal University of Sergipe (UFS), and Titular Professor of the Medical School, Tiradentes University (UNIT), Aracaju, Sergipe, Brazil.

${ }^{2}$ Medical student at the Federal University of Sergipe (UFS), Aracaju, Sergipe, Brazil.

${ }^{3}$ Medical Student, University Center of Volta Redonda (UNIFOA), Volta Redonda, Rio de Janeiro, Brazil.

${ }^{4}$ Titular Professor, Medical School of Tiradentes University (UNIT), Aracaju, Sergipe, Brazil.
} 
There are several anatomical studies in the literature reporting the importance of morphometric variations of the occipital condyles (Kumar \& Nagar, 2014, Kavitha et al., Natsis et al., Bayat et al., Das et al., Naderi et al., Ozer et al., Kizilkanat et al., Muthukumar et al., Avci et al., 2011, Bozbug `a et al., 1999, Kalthur et al., 2014, El-Gaidi et al., 2014, Gapert et al., 2009) and radiological studies have also been conducted (Avci et al., Le et al., 2011, Hong et al., 2011, Noble \& Smoker, 1996). Knowledge of the topography of different neurovascular structures located around the region of the occipital condyles is highly important with regard to conducting neurosurgical procedures (transcondylar approach) and obtaining good results. Notions of this knowledge should be one of the main issues to be analyzed during the preoperative decision-making process (Kumar \& Nagar, Naderi et al., Ozer et al., Kizilkanat et al., Avci et al.).

Most of the descriptions found in textbooks do not deal with anatomical variations of the occipital condyles (Gardner et al., 1988; Hollinshead, 1991; Drake et al., 2010; Moore et al., 2011). This indicates that there is still a need for studies on the morphometric variations of the occipital condyles. The present study had the aim of determining the frequency of occurrence of different morphological types of occipital condyles.

\section{MATERIAL AND METHOD}

We analyzed 214 occipital condyles in dry human skulls belonging to the Forensic Anatomy and Anthropology Study and Research Center of Tiradentes University (UNIT), Aracaju, Sergipe, Brazil. Skulls that appeared to be complete in the region of the occipital condyles and which were identified regarding sex and age were analyzed. The classification of the morphological types of occipital condyles was determined through examining digitized photographic images that had been obtained using a digital camera (Sony DSLR-A100K) and had been save in JPEG format (Joint Photographic Experts Group). The present study was approved by the Research Ethics Committee of the Federal University of Sergipe, under protocol number 0357.0.107.000-11.

\section{RESULTS}

Among the 107 skulls that were analyzed in the present study, $64(59.8 \%)$ were male and $43(40.2 \%)$ were female. Their ages ranged from 11 to 91 years, with a mean of 57.56 years. The morphological types that were found are represented in Fig. 1 and their frequency of distribution according to sex is presented in Table I. It can be seen that the type in an "8" shape was most prevalent, followed by the "S" and ring types, and that condyles of irregular shape were least prevalent. Symmetrical and asymmetrical forms were found respectively in $26.2 \%$ and $73.8 \%$ of the skulls.

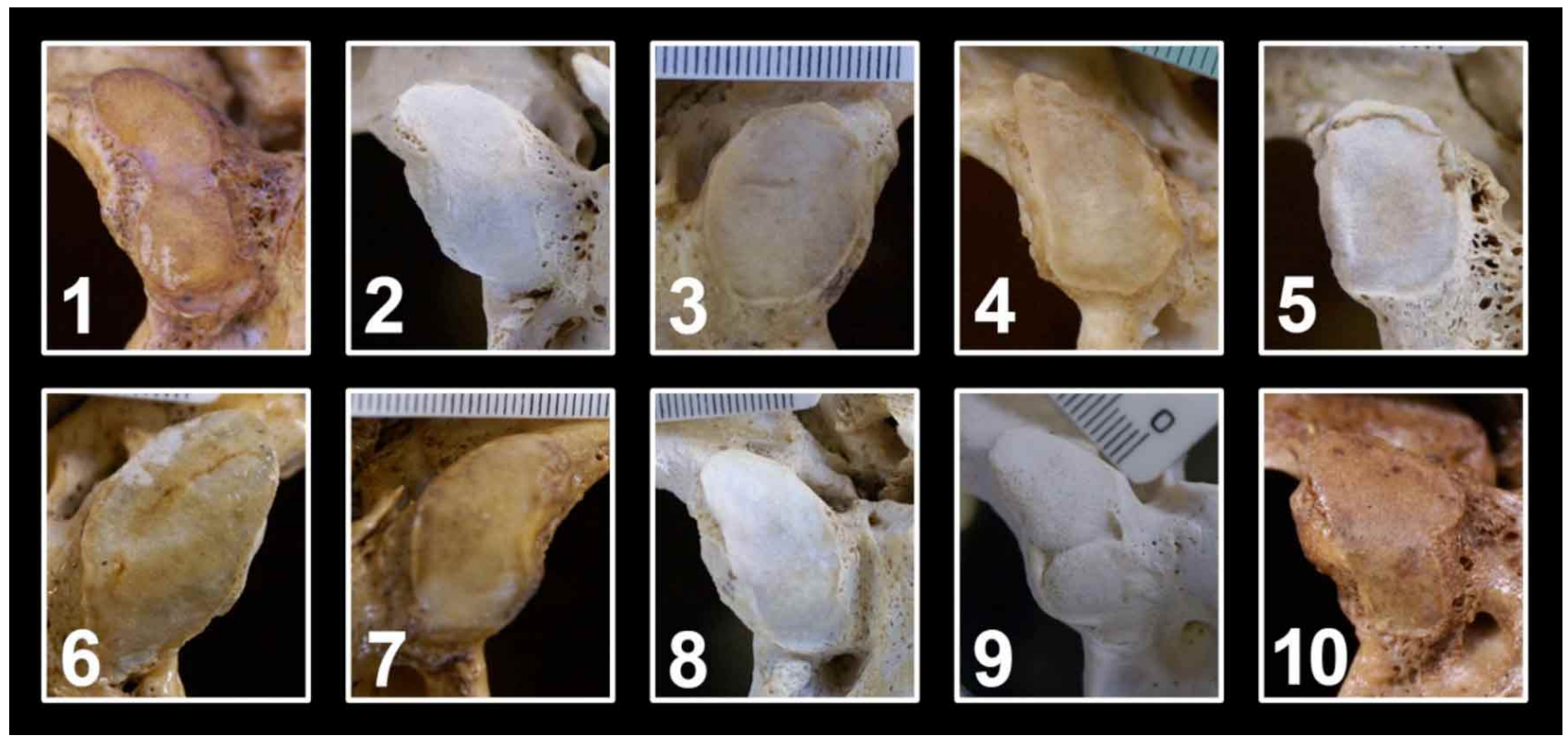

Fig. 1. Morphology of occipital condyles. 1) "8” shape, 2) "S" shape, 3) ring, 4) triangular, 5) quadrilateral, 6) biconvex, 7) reniform, 8) oval, 9) condyle in two parts, 10) irregular. 
Table I. Distribution of different morphological types of occipital condyle, according to sex.

\begin{tabular}{|c|c|c|c|c|c|c|c|c|c|c|}
\hline \multirow{4}{*}{ Morphological type } & \multicolumn{10}{|c|}{ Sex } \\
\hline & \multicolumn{4}{|c|}{ Male } & \multicolumn{4}{|c|}{ Female } & \multicolumn{2}{|c|}{ Total } \\
\hline & \multicolumn{2}{|c|}{ Right } & \multicolumn{2}{|c|}{ Left } & \multicolumn{2}{|c|}{ Right } & \multicolumn{2}{|c|}{ Left } & & \\
\hline & $\mathrm{n}$ & $\%$ & $\mathrm{n}$ & $\%$ & $\mathrm{n}$ & $\%$ & $\mathrm{n}$ & $\%$ & $\mathrm{n}$ & $\%$ \\
\hline "8" & 7 & 3.3 & 18 & 8.4 & 8 & 3.7 & 8 & 3.7 & 41 & 19.2 \\
\hline "S" & 16 & 7.5 & 9 & 4.2 & 7 & 3.3 & 7 & 3.3 & 39 & 18.2 \\
\hline Ring & 10 & 4.7 & 12 & 5.6 & 5 & 2.3 & 4 & 1.9 & 31 & 14.5 \\
\hline Triangular & 3 & 1.4 & 5 & 2.3 & 7 & 3.3 & 5 & 2.3 & 20 & 9.3 \\
\hline Quadrilateral & 4 & 1.9 & 6 & 2.8 & 1 & 0.5 & 7 & 3.3 & 18 & 8.4 \\
\hline Bic onvex & 7 & 3.3 & 4 & 1.9 & 4 & 1.9 & 2 & 0.9 & 17 & 7.9 \\
\hline Reniform & 6 & 2.8 & 2 & 0.9 & 5 & 2.3 & 4 & 1.9 & 17 & 7.9 \\
\hline Oval & 4 & 1.9 & 5 & 2.3 & 3 & 1.4 & 1 & 0.5 & 13 & 6.1 \\
\hline Condyle in two parts & 5 & 2.3 & 3 & 1.4 & 1 & 0.5 & 1 & 0.5 & 10 & 4.7 \\
\hline Irregular & 2 & 0.9 & 0 & 0.0 & 2 & 0.9 & 4 & 1.9 & 8 & 3.7 \\
\hline Total & 64 & 29.9 & 64 & 29.9 & 43 & 20.1 & 43 & 20.1 & 214 & 100 \\
\hline
\end{tabular}

Table II. Most frequent morphological types of occipital condyle in different studies.

\begin{tabular}{|c|c|c|c|}
\hline S tudy & $\begin{array}{c}\text { Morphological } \\
\text { type }\end{array}$ & Population & $\%$ \\
\hline Ozer et al. & Oval & Turkish & 59.67 \\
\hline Fetou h & Reniform & Egyptian & 22 \\
\hline Naderi et al. & Oval & Turkish & 50 \\
\hline Sinha et al. & S & Indian & 25 \\
\hline Bayat et al. & Reniform & Iranian & 34.4 \\
\hline Kalthur et al. & $" 8 "$ & Indian & 22.5 \\
\hline Natsis et al. & "S" & Greek & 30.7 \\
\hline Present study & $" 8 "$ & Brazilian & 19.2 \\
\hline
\end{tabular}

\section{DISCUSSION}

Several classifications have been created to define different morphological types of occipital condyle, but without determining the prevalence of each of these types (Bozbug a et al.; Olivier, 1975; Guidotti, 1984). Guidotti analyzed 741 skulls belonging to the Institute of Anatomy of the University of Siena and propose a classification of occipital condyles based on (1) division of their surface into planes; (2) partition without interruption of the joint surface; (3) partition with an evident angle but without separation of the two surfaces; and (4) duplication of condyles. Bozbuga et al. classified occipital condyles as follows: (1) two forms of semicircle; (2) oval; (3) lozenge; (4) bean; (5) prismatic; (6) flattened; (7) convex; (8) flattened convex; (9) plane; (10) short and wide; (11) planar and long; and (12) small and convex.

Table II shows the variance and discordance regarding the morphological types of occipital condyles, along with their prevalence. From an analysis on skulls from the Turkish population, Ozer et al. and Naderi et al. concluded that occipital condyles of oval shape were the commonest. According to Sinha et al. (2014) and Natsis et al. the "S" shape was the main type. However, Bayat et al. and Fetouh \& Awadalla (2009) reported that occipital condyles of reniform shape were most prevalent. In the present study, the main morphological type of occipital condyle was found to be the " 8 " shape. A similar finding was reported by Kalthur et al. from a study on individuals in the Indian population. A comparison of incidence rates among morphological types of occipital condyle reported by some authors is shown in Table III.

Table III. Morphological comparison of occipital condyles in various studies.

\begin{tabular}{|c|c|c|c|c|c|c|c|c|c|c|c|c|c|c|c|c|}
\hline \multirow[t]{3}{*}{ Authors } & \multicolumn{16}{|c|}{ Shape of occipital condyles } \\
\hline & $\mathbf{n}$ & 1 & 2 & 3 & 4 & 5 & 6 & 7 & 8 & 9 & 10 & 11 & 12 & 13 & 14 & 15 \\
\hline & & & & & & & & $\%$ & & & & & & & & \\
\hline Naderi et al. & 404 & 50 & 3.5 & 23.2 & 4.2 & 9 & 4 & 0.8 & 5.5 & - & - & - & - & - & - & - \\
\hline Kalthur et al. & 142 & 22.5 & 12 & 14.8 & 22.5 & 10.6 & 1.4 & 4.9 & 11.3 & - & - & - & - & - & - & - \\
\hline Ozer et al. & 704 & 59.7 & 23 & 4 & 4.5 & 4.2 & 2.3 & 0.3 & 1.7 & - & - & - & - & - & - & - \\
\hline Fetouh \&Awadalla & 200 & 16 & 22 & 19 & 12 & 6 & 7 & 13 & - & 5 & - & - & - & - & - & - \\
\hline Sinha et al. & 72 & - & 12.5 & 25 & 13.9 & 19.4 & - & - & - & 5.6 & 16 & 6.9 & - & - & - & - \\
\hline Kavitha et al. & 290 & 30.7 & - & - & - & - & - & - & - & - & - & - & 30 & - & 31 & 7.9 \\
\hline Natsis et al. & 286 & 7.6 & 6.2 & 30.7 & 12.6 & 16.2 & 4.4 & 16.6 & 5.8 & - & - & - & - & - & - & - \\
\hline Present study & 214 & 6.1 & 7.9 & 18.2 & 19.2 & 9.3 & 14.5 & 4.7 & - & 8.4 & 3.7 & - & - & 7.9 & - & - \\
\hline
\end{tabular}

1. oval; 2. reniform; 3. "S"; 4. "8"; 5. triangular; 6. ring; 7. condyle in two parts; 8. deformed; 9. quadrilateral; 10. irregular; 11. oval/ring; 12. oblong; 13. biconvex; 14. crescent; 15. lozenge. 
CONCLUSIO. In the present study, occipital condyles of " 8 " and " $\mathrm{S}$ " shape were the main types found. Among the male skulls, the " 8 " shape was most prevalent on the right side, while the " $\mathrm{S}$ " shape was most prevalent on the right side. Among the female skulls, these two types had the same distribution bilaterally.

ARAGÃO, J. A.; DE SANTANA, G. M.; DA CRUZ DE MORAES, R. Z.; ARAGÃ̃, I. C. S.; ARAGÃO, F. M. S.; REIS, P. F. Análisis morfológico de los cóndilos occipitales. Int. J. Morphol., 35(3):1129-1132, 2017.

RESUMEN: La mayor parte de los estudios anatómicos y biomecánicos de la unión cráneo-vertebral han sido realizados sobre el análisis morfológico o de la morfometría de los cóndilos occipitales. Algunos de estos trabajos tienen previsto importantes hallazgos basados en diferentes procedimientos quirúrgicos. De tal forma, el tamaño y ángulo del cóndilo occipital bien como su localización de los orificios intracraneales y extracraneales del canal hipogloso son de gran importancia, ya que pueden afectar a los enfoques laterales de la unión cráneovertebral. El objetivo del estudio fue determinar la prevalencia de los tipos morfológicos de cóndilos occipitales. Fueron analizados 214 cóndilos de 107 cráneos secos de humanos y la clasificación de los tipos morfológicos fue determinada a partir de los análisis de estudio de imágenes fotográficas digitalizadas. De los 107 cráneos que fueron analizados, $59,8 \%$ eran de sexo masculino y $40,2 \%$ de sexo femenino, cuyas edades comprendidas entre 11 y 91 años con una media de 57.56 años. De un total de 10 tipos morfológicos de los cóndilos occipitales encontrados, más del $50 \%$ eran de tipo ocho, $\mathrm{S}$ y anillo. Los cóndilos en forma de " 8 " $\mathrm{y}$ " $\mathrm{S}$ " fueron los principales tipos encontrados, en el sexo masculino, la forma en "8" prevaleció en el lado izquierdo, y el tipo morfológico en "S", en el lado derecho del cráneo. Mientras que en el sexo femenino esos dos tipos tuvieron una equitativa distribución bilateral.

PALABRAS ClaVE: Cráneo; Cóndilo occipital; Articulación atlanto-occipital; Anatomía quirúrgica; Anomalías craneofaciales; Morfología; Hueso occipital.

\section{REFERENCES}

Avci, E.; Dagtekin, A.; Ozturk, A. H.; Kara, E.; Ozturk, N. C.; Uluc, K.; Akture, E., \& Baskaya, M. K. Anatomical variations of the foramen magnum, occipital condyle and jugular tubercle. Turk. Neurosurg., 21(2):181-90, 2011.

Bayat, P.; Bagheri, M.; Ghanbari, A. \& Raoofi, A. Characterization of occipital condyle and comparison of its dimensions with head and foramen magnum circumferences in dry skulls of Iran. Int. J. Morphol., 32(2):444-8, 2014.

Bozbug `a, M.; Oztürk, A.; Bayraktar, B.; Ari, Z.; Sahinog `lu, K.; Polat, G. \& Gürel, I. Surgical anatomy and morphometric analysis of the occipital condyles and foramen magnum. Okajimas Folia Anat. Jpn., 75(6):32934, 1999.

Das, S.; Suri, R. \& Kapur, V. Unusual occipital condyles of the skull: an osteological study with clinical implications. São Paulo Med. J., 124(5):278-9, 2006.

Drake, R. L.; Vogl, A. W. \& Mitchell, A. Gray's Anatomia para Estudantes. 2nd ed. Rio de Janeiro, Elsevier, 2010.

El-Gaidi, M. A.; Eissa, E. M. \& El-Shaarawy, E. A. Free-hand placement of occipital condyle screws: a cadaveric study. Eur. Spine J., 23(10):2182-8, 2014.
Fetouh, F. \& Awadalla, A. Morphometric analysis of the occipital condyle and its surgical implications in transcondylar approach. Skull Base, 19:A023, 2009.

Gapert, R.; Black, S. \& Last, J. Sex determination from the occipital condyle: discriminant function analysis in an eighteenth and nineteenth century British sample. Am. J. Phys. Anthropol., 138(4):384-94, 2009.

Gardner, E.; Gray, D. J. \& O' Rahilly, R. Anatomy: A Regional Study of Human Structure. 4th ed. Rio de Janeiro, W. B. Saunders, 1988.

Guidotti, A. Morphometrical considerations on occipital condyles. Anthropol. Anz., 42(2):117-9, 1984

Hollinshead, W. H. Anatomia Humana. 4th ed. Rio de Janeiro, Interlivros, 1991.

Hong, J. T.; Takigawa, T.; Sugisaki, K.; Espinoza Orías, A. A.; Inoue, N. \& An, H. S. Biomechanical and morphometric evaluation of occipital condyle for occipitocervical segmental fixation. Neurol. Med. Chir. (Tokyo), 51(10):701-6, 2011.

Kalthur, S. G.; Padmashali, S.; Gupta, C. \& Dsouza, A. S. Anatomic study of the occipital condyle and its surgical implications in transcondylar approach. J. Craniovertebr. Junction Spine, 5(2):71-7, 2014.

Kavitha, S.; Chandrasekaran, S.; Anand, A. \& Shanthi, K. C. Morphometric study of occipital condyles in adult human skulls. I. J. C. R. R., 5(15):314, 2013.

Kizilkanat, E. D.; Boyan, N.; Soames, R. \& Oguz, O. Morphometry of the hypoglossal canal, occipital condyle, and foramen magnum. Neurosurg. Q., 16(3):121-5, 2006.

Kumar, A. \& Nagar, M. Human adult occipital condyles: A morphometric analysis. Res. Rev. J. Med. Health Sci., 3(4):112-6, 2014.

Le, T. V.; Dakwar, E.; Hann, S.; Effio, E.; Baaj, A. A.; Martinez, C.; Vale, F. L. \& Uribe, J. S. Computed tomography-based morphometric analysis of the human occipital condyle for occipital condyle-cervical fusion. $J$. Neurosurg. Spine, 15(3):328-31, 2011.

Moore, K. L.; Dalley, A. F. \& Agur, A. M. R. Anatomia Orientada para a Clínica. 6a ed. Rio de Janeiro, Guanabara Koogan, 2011.

Muthukumar, N.; Swaminathan, R.; Venkatesh, G. \& Bhanumathy, S. P. A morphometric analysis of the foramen magnum region as it relates to the transcondylar approach. Acta Neurochir. (Wien), 147(8):889-95, 2005.

Naderi, S.; Korman, E.; Citak, G.; Güvençer, M.; Arman, C.; Senog lu, M.; Tetik, S. \& Arda, M. N. Morphometric analysis of human occipital condyle. Clin. Neurol. Neurosurg., 107(3):191-9, 2005.

Natsis, K.; Piagkou, M.; Skotsimara, G.; Piagkos, G. \& Skandalakis, P. A morphometric anatomical and comparative study of the foramen magnum region in a Greek population. Surg. Radiol. Anat., 35(10):925-34, 2013.

Noble, E. R. \& Smoker, W. R. The forgotten condyle: the appearance, morphology, and classification of occipital condyle fractures. A. J. N. R. Am. J. Neuroradiol., 17(3):507-13, 1996.

Olivier, G. Biometry of the human occipital bone. J. Anat., 120(Pt.3):507$18,1975$.

Ozer, M. A.; Celik, S.; Govsa, F. \& Ulusoy, M. O. Anatomical determination of a safe entry point for occipital condyle screw using three-dimensional landmarks. Eur. Spine J., 20(9):1510-7, 2011.

Sinha, M. B.; Trivedi, S.; Siddiqui, A. U. \& Rathore, M. Occipital condyle and its relevance during surgery. N. J. C. A., 3(4):209-4, 2014.

Corresponding author:

José Aderval Aragão

Rua Aloisio Campos 500

Bairro Atalaia

Aracaju, Sergipe

CEP: 49035-020

Received: 12-04-2017

BRAZIL

Accepted: 25-07-2017 